\begin{tabular}{|c|c|c|}
\hline JURNAL PENELITIAN KESMASY & VOL. 1 NO. 2 & $\begin{array}{c}\text { EDITION: NOVEMBER 2018 - } \\
\text { APRIL } 2019\end{array}$ \\
\hline & http://ejournal.delihusada.ac.id/index.php/JPKSY & \\
\cline { 2 - 3 } RECEIVED: 16 FEBRUARI 2019 & REVISED: 18 MARET 2019 & ACCEPTED: 20 APRIL 2019 \\
\hline
\end{tabular}

\title{
HUBUNGAN PENGETAHUAN DAN SIKAP REMAJA TENTANG KESEHATAN REPRODUKSI DENGAN PERILAKU SEKSUAL PRANIKAH SISWA
}

\author{
Silvia Mona \\ Universitas Batam, Batam, Indonesia \\ silviamona88@univbatam.ac.id
}

\begin{abstract}
This study aims to determine whether there is a relationship between knowledge and attitudes about reproductive health with premarital sexual behavior. The design of this study is an analytical survey with a cross-sectional approach. The population is 470 students and the total sample of this study is 82 students. Time to take in April-May 2018, the research instrument uses a questionnaire. Data analysis used the chi-square statistical test. The results of the study of knowledge were mostly 64 respondents (78.0\%) with good knowledge, students who mostly had negative attitudes as much as 48 responses (41.5\%), students who had premarital sexual behavior the majority were 66 respondent $(80.5 \%)$. The conclusion of this study is that there is a relationship between attitudes and behaviors to increase knowledge, attitudes and behaviors about premarital sex.
\end{abstract}

Keywords: Sexual behavior, reproductive health, premarital knowledge

\section{PENDAHULUAN}

Remaja didefinisikan sebagai masa peralihan dari masa kanak-kanak ke masa dewasa. Batasan usia remaja menurut World Health Organization (WHO) adalah 12 sampai 24 tahun. Remaja sebenarnya dalam periode/fase yang tidak jelas. Mereka sudah tidak termasuk dalam golongan anak- anak, tetapi belum juga diterima secara penuh untuk masuk kegolongan orang dewasa. Masalah yang sering dialami oleh remaja saat ini adalah masalah seputar seksualitas, terutama seks pranikah. Seks pranikah merupakan salah satu fenomena yang kian hari makin marak. Hal ini terbukti dari beberapa penelitian yang menunjukkan bahwa 20 tahun yang lalu yang menyetujui melakukan seks pranikah hanya sekitar 1,2\% - 9,6\%, lalu 10 tahun kemudian naik menjadi diatas $10 \%$ dan 5 tahun kemudian angka itu naik menjadi $17 \%$ (WHO, 2011).

Berdasarkan data WHO yang melakukan penelitian dibeberapa Negara berkembang menunjukkan $40 \%$ remaja pria umur 18 tahun dan remaja putri umur 18 tahun sekitar $40 \%$ telah melakukan hubungan seks meskipun tanpa ada ikatan pernikahan. Akibat dari hubungan seksual pranikah, sekitar $12 \%$ telah positif terkena Penyakit Menular Seksual, sekitar $27 \%$ positif HIV, dan $30 \%$ remaja putri telah hamil, setengah dari mereka melahirkan namun setengahnya lagi melakukan aborsi (SKRT, 2011).

Penelitian yang dilakukan oleh SDKI (Survei Demografi dan Kesehatan Indonesia) menunjukkan sekitar 16,9\% wanita setuju untuk melakukan hubungan seks pranikah dan sekitar $12,4 \%$ pria yang setuju. Sekitar $11 \%$ pada pria yang tidak tamat SD menyetujui hubungan seks pranikah sedangkan $8,8 \%$ pria yang tamat SMTA setuju terhadap seks pranikah. Disisi lain, sekitar 4,9\% wanita tidak tamat SD menyetujui seks pranikah dan $4,5 \%$ wanita yang tamat SMTA setuju terhadap seks prnikah.

Suatu penelitian yang dilakukan di salah satu perguruam tinggi negeri di Indonesia menunjukkan bahwa sebagian remaja telah melakukan hubungan seks pranikah berupa, kissing $66,8 \%$, necking $52 \%$, petting $29,2 \%$, oral seks $25,6 \%$, intercourse $20,4 \%$ dan anal seks sebanyak 6,8\%.4 Pengetahuan yang rendah akan mempengaruhi sikap remaja dalam bersikap mengenai seks pranikah disertai dengan kuatnya pengaruh teman sebaya pada usia remaja, menjadikan remaja mempunyai tindakan seksual yang tidak sehat yang pada akhirnya mendekatkan mereka kepada resiko terinfeksi berbagai macam penyakit menular seksual, termasuk didalamnya HIV dan AIDS (SDKI, 2012). 


\begin{tabular}{|c|c|c|}
\hline JURNAL PENELITIAN KESMASY & VOL. 1 NO. 2 & $\begin{array}{c}\text { EDITION: NOVEMBER } 2018- \\
\text { APRIL } 2019\end{array}$ \\
\hline & http://ejournal.delihusada.ac.id/index.php/JPKSY & \\
\hline
\end{tabular}

Hasil Sensus Penduduk menunjukan bahwa jumlah penduduk Indonesia sebesar 237,6 juta jiwa, 63,4 juta diantaranya adalah remaja yang terdiri dari laki-laki sebanyak 32.164.436 jiwa $(50,70 \%)$ dan perempuan sebanyak 31.279 .012 jiwa (49,30\%). Besarnya penduduk remaja akan berpengaruh pada pembangunan aspek sosial, ekonomi maupun demografi baik saat ini maupun dimasa yang akan datang. Menurut survei demografi dan Kesehatan Indonesia Remaja (SDKI-R) tahun 2011, penduduk remaja perlu mendapat perhatian serius karena remaja termasuk dalam usia sekolah dan usia kerja, mereka sangat beresiko terhadap masalahmasalah kesehatan reproduksi yaitu perilaku seksual pranikah, penggunaan Narkotika Alkohol Psikotrkopika dan Zat Adiktif (NAPZA) dan HIV/AIDS (BKKBN, 2011).

Menurut BKKBN, program kesehatan reproduksi remaja adalah untuk membantu remaja agar memiliki pengetahuan, kesadaran, sikap dan perilaku hidup reproduksi sehat bertanggungjawab, melalui advokasi, promosi, $\mathrm{KIE}$, konseling dan pelayanan kepada remaja yang memiliki permasalahan khusus. Materi kesehatan reproduksi remaja mencakup aspek kehidupan remaja yang terkait dengan pengetahuan, sikap dan perilaku kehidupan seksual serta berkeluarga. Di Jawa Tengah pada tahun 2011 khususnya pada Kota semarang, tingkat pengetahuan kesehatan reproduksi menunjukan $43,2 \%$ memeliki pengetahuan rendah, $37,2 \%$ memiliki pengetahuan cukup dan 19,5 memeiliki pengetahuan yang baik (PKBI, 2011).

Akibat dari kurangnya informasi kesehatan reproduksi salah satunya adalah remaja sudah melakukan hubungan seksual secara aktif tanpa pengetahuan yang cukup. BKKBNpada tahun 2011 mengeluarkan data remaja yang sudah tidak perawan lagi. Hasilnya yaitu remaja yang sudah tidak perawan lagi dibeberapa kota besar seperti, Jakarta sebesar $51 \%$, Bogor sebesar $51 \%$, Tangerang sebesar $51 \%$, Surabaya sebesar $54 \%$, Medan sebesar $52 \%$, Bandung sebesar $47 \%$, dan Yogyakarta sebesar $37 \%$. Selain itu diketahui pula bahwa rentang usia remaja yang pernah melakukan hubungan seksual diluar nikah adalah 13-18 tahun (Ganiajri, 2012).

Sikap merupakan faktor predisposisi dalam menentukan perilaku seseorang. Sikap merupakan proses evaluasi yang bersifat internal, subjektif, berlangsung dalam diri seseorang dan tidak dapat diamati secara langsung. Sikap remaja terhadap kesehatan reproduksi diperlihatkan dengan adanya kecenderungan menolak atau mendukung perilaku seks (Reynie, 2016).

Kurangnya pemahaman tentang perilaku seksual pada remaja amat merugikan bagi remaja sendiri termasuk keluarganya, sebab pada masa ini remaja mengalami perkembangan yang penting yaitu kognitif, emosi, sosial, dan seksual. Perkembangan ini mulai dari usai 12 tahun sampai 20 tahun. Kurangnya pemahaman ini disebabkan oleh berbagai faktor antara lain: adat istiadat, budaya, agama, dan kurangnya pemahaman dari sumber yang benar. Kurangnya pemahaman ini justru amat merugikan kelompok remaja dan keluarganya (Soetjiningsih, 2011)

Berdasarkan data Perkumpulan Keluarga Berencana Indonesia (PKBI) Jawa Tengah, pada tahun 2013 kasus remaja yang melakukan seks pranikah sebanyak 765 orang, hamil sebelum menikah 367 orang, yang terkena infeksi menular seksual 275 orang, aborsi 166 orang. Kasus tersebut meningkat pada tahun 2010, remaja yang melakukan hubungan seksual pranikah sebanyak 863 orang, hamil sebelum menikah 452 orang, yang terkena infeksi menular seksual 283 orang, aborsi 244 orang. Sedangkan survei yang dilakukan oleh youth center pilar PKBI Jawa Tengah pada tahun 2011 dengan 99 responden siswa SMA di Jawa Tengah. Didapatkan data remaja sebagai berikut: yang berpegangan tangan $82,8 \%$, berpelukan $68,7 \%$, mencium pipi $64,6 \%$, berciuman bibir $62,6 \%$, saling meraba dada dan kelamin $32,3 \%$, melakukan petting $20,2 \%$, melakukan oral seks $8,1 \%$, melakukan hubungan seks vagina $14,1 \%$ (Kustanti, 2013).

Menurut Elcya (2014) dalam penelitiannya mengenai Hubungan Antara Pengetahuan dan Sikap Remaja Dengan Tindakan Seks Pranikah pada Siswa Kelas XI Di SMK Negeri 2 Manado dengan metode pendekatan potong lintang.Sampel pada penelitian ini berjumlah 82 responden remaja yang sudah masuk dalam kriteria. Dari 82 responden remaja secara keseluruhan menunjukkan bahwa sebagian besar remaja berpengetahuan baik dengan presentase $52,4 \%$, sikap remaja didominasi oleh sikap positif dengan 


\begin{tabular}{c|c|c}
\hline JURNAL PENELITIAN KESMASY & VOL. 1 NO. 2 & $\begin{array}{c}\text { EDITION: NOVEMBER 2018 - } \\
\text { APRIL 2019 }\end{array}$ \\
\hline & http://ejournal.delihusada.ac.id/index.php/JPKSY & \\
\cline { 2 - 3 } RECEIVED: 16 FEBRUARI 2019 & REVISED: 18 MARET 2019 & ACCEPTED: 20 APRIL 2019 \\
\hline
\end{tabular}

presentase 54,9\%, dan tindakan remaja didominasi dengan tindakan baik yaitu $61,0 \%$.

Berdasarkan data dari Dinas Pendidikan Kota Batam didapatkan jumlah siswa terbesar di Batam yaitu SMPN 10 Bengkong dengan jumlah murid 1389 (DINKES, 2017). Berdasarkan data awal melalui wawancara singkat dengan 15 siswi kelas IX di SMPN 10 Batam, 10 diantaranya mengatakan bahwa mereka memiliki pengetahuan yang kurang tentang seks pranikah, tidak paham dengan bahaya dan resiko jika melakukan hubungan seks pranikah. Mereka juga tidak tahu bagaimana cara atau sikap yang harus dilakukan untuk menghindari seks pranikah.

Berdasarkan informasi yang diperoleh pada saat melakukan pra survei melalui wawancara dengan pihak sekolah yaitu didapatkan siswa yang tiba-tiba menghilang dan tidak pernah masuk sekolah lagi untuk mengikuti pelajaran seperti biasanya dalam jangka waktu cukup lama dikarena kan sudah hamil di luar nikah. Berdasarkan latar belakang diatas, penulis tertarik untuk melakukan penelitian ini yang berjudul Hubungan pengetahuan dan sikap remaja tentang kesehatan reproduksi dengan perilaku seksual pranikah di SMPN 10 Batam

\section{METODE PENELITIAN}

Jenis penelitian ini adalah penelitian survei analitik dengan pendekatan Cross Sectional yaitu sebuah penelitian yang dilakukan dalam waktu sekali saja. Tidak ada perulangan dalam pengambilan data (Rumengan,2012). Sampel dalam penelitian ini adalah siswa SMP Negeri 10 Batam yang berjumlah 82 orang.

\section{HASIL DAN PEMBAHASAN}

\section{Pengetahuan}

Hasil penelitian menunjukkan bahwa dari 82 responden, memiliki pengetahuan baik ada sebanyak 64 responden $(78,0 \%)$ sedangkan pengetahuan yang kurang baik sebanyak 18 responden (22,0\%). Hal ini menunjukan bahwa siswa/i kelas VIII memiliki pengetahuan yang baik.

Pengetahuan atau Kognitif merupakan domain yang sangat penting dalam tindakan seseorang. Sehingga sangat diperlukan sekali untuk meningkatkan pengetahuan remaja. Pengetahuan kesehatan reproduksi sangat penting untuk membatasi perilaku seksual yang kian bebas pada usia remaja terlebih pada masa remaja awal. Hal ini juga dikuatkan oleh penelitian Riyanto (2010).

Salah satu unsur yang diperlukan agar dapat berbuat sesuatu adalah mempunyai pengetahuan dan jika seseorang menghendaki sesuatu dapat dikerjakan dengan terus menerus maka diperlukan pengetahuan yang positif tentang apa yang dikerjakan, dengan kata lain tindakan yang dilandasi pengetahuan akan lebih langgeng dibandingkan dengan tindakan yang tanpa pengetahuan yang baik tentang kesehatan reproduksi maka diharapkan remaja dapat mengontrol perilaku seksualnya (Notoatmodjo, 2010).

Hasil penelitian ini sejalan dengan teori menurut Annadharah (2011), Pengetahuan tentang seksualitas dapat menjadikan individu memiliki sikap dan tingkah laku seksual yang sehat dan bertanggung jawab, oleh karena itu remaja yang memilki pemahaman secara benar dan proporsional tentang kesehatan reproduksi cenderung memahami perilaku serta alternatif cara yang dapat digunakan untuk menyalurkan dorongan seks secara sehat dan bertanggung jawab.

Berdasarkan penelitian yang dilakukan oleh Sari (2014) dengan judul hubungan pengetahuan dan sikap dengan perilaku seksual pada anak SMK bahwa Hubungan Pengetahuan dengan perilaku seksual pranikah pada remaja di SMK Patris ada sebanyak 24 $(42,1 \%)$ siswa yang berpengetahuan baik melakukan perilaku seksual pranikah, sedangkan diantara siswa yang berpengetahuan kurang baik, ada 33 (57,9\%) yang melakukan perilaku seksual pranikah. Dari hasil uji statistik diperoleh nilai $p$-value 0.000 maka dapat disimpulkan adanya Hubungan Pengetahuan dengan perilaku seksual pranikah pada remaja di SMK PATRIA.

Berdasarkan hasil penelitian yang dilakukan oleh peneliti maka dapat disimpulkan bahwa sebagian besar siswa/I memiliki pengetahuan yang baik, meskipun mereka baru kelas VIII namun pengetahuan mereka sudah begitu paham dengan tentang kesehatan reproduksi dengan perilaku seks pranikah pada siswa/I.

\section{Sikap}

Sikap siswa menunjukan bahwa dari 82 responden yang memiliki sikap positif sebanyak 34 responden $(41,5 \%)$ dan sikap negatif sebanyak 48 responden $(58,5 \%)$. Hal 


\begin{tabular}{c|c|c}
\hline JURNAL PENELITIAN KESMASY & VOL. 1 NO. 2 & $\begin{array}{c}\text { EDITION: NOVEMBER 2018 - } \\
\text { APRIL 2019 }\end{array}$ \\
\hline & http://ejournal.delihusada.ac.id/index.php/JPKSY & \\
\cline { 2 - 3 } RECEIVED: 16 FEBRUARI 2019 & REVISED: 18 MARET 2019 & ACCEPTED: 20 APRIL 2019 \\
\hline
\end{tabular}

ini menunjukan bahwa siswa/I kelas VII memiliki sikap yang negatif.

Salah satu bentuk stimulus sikap dari luar adalah pengetahuan maka dengan remaja yang mendapat informasi yang benar tentang seksual pranikah maka mereka akan cenderung mempunyai sikap negatif. Seseorang setelah mengetahui stimulus atau objek kesehatan, kemudian mengadakan penilaian atau pendapat terhadap apa yang diketahui, proses selanjutnya diharapkan akan dapat melaksanakan atau mempraktekkan apa yang diketahui atau disikapi sehingga pengetahuan seksual pranikah dapat mempengaruhi sikap individu tersebut terhadap seksual pranikah (Notoatmodjo, 2011).

Hasil penelitian ini sejalan dengan teori Azwar (2011) Sikap negatif terdapat kecenderungan untuk menjauhi, menghindari, membenci, tidak menyukai obyek tertentu. Sikap negatif pada penelitian ini dipengaruhi oleh faktor antara lain pengalaman pribadi, kebudayaan, orang lain yang dianggap penting, media massa, institusi atau lembaga pendidikan/ agama dan faktor emosi dalam diri individu.

Hasil dari penelitian ini didapatkan ada hubungan antara sikap dengan perilaku seksual pranikah. Hal ini sesuai dengan penelitian yang dilakukan sari (2014) Hasil analisis hubungan sikap dengan perilaku seksual pranikah pada remaja di SMK PATRIA menunjukkan bahwa ada sebanyak 43 $(75,4 \%)$ siswa yang mempunyai sikap negatif melakukan perilaku seksual pranikah, sedangkan diantara siswa yang mempunyai sikap positif, ada 14 (24,6\%) yang melakukan perilaku seksual pranikah. Dari hasil uji statistik diperoleh nilai $p$-value 0.000 . Menurut Sarwono (2012), semakin tinggi sikap positif (permisif) terhadap perilaku seksual pada remaja mengakibatkan semakin besar kecenderungan remaja untuk melakukan hubungan fisik yang lebih jauh dengan lawan jenis.

Berdasarkan hasil penelitian hal ini terbukti dari hasil kuesioner yang telah diisi oleh responden didapatkan sikap negatif lebih besar dibandingkan sikap positif karena rata-rata responden mengganggap bahwa Informasi tentang seks dan kesehatan reproduksi tidak penting bagi remaja karena menjelaskan perubahan-perubahan baik secara fisik maupun anatomi.

\section{Perilaku}

Perilaku siswa menunjukkan bahwa dari 82 responden yang memiliki perilaku sesksual pranikah yang baik sebanyak 66 responden $(80,5 \%)$ dan perilaku buruk sebanyak 16 responden (19,5\%). Hal ini menunjukkan bahwa siswa/siswi memiliki perilaku yang baik.

Perilaku yang didasari oleh pengetahuan umumnya langgeng daripada perilaku yang tidak didasari pengetahuan. Rendahnya pengetahuan tentang masalah seksual disebabkan oleh kurang informasi tentang seksual yang didapatkan oleh remaja. Hal itu membuat remaja ingin mencari tahu lebih dari berbagai jenis media massa. Terkadang informasi yang didapatkan justru menyesatkan dan tidak lengkap. Hal ini justru lebih berbahaya dari pada tidak tahu sama sekali, tetapi ketidaktahuan sama sekali itu juga membahayakan. Pengetahuan yang setengahsetengah tidak hanya mendorong remaja tersebut untuk mencoba melakukan, tetapi juga menimbulkan kesalahan persepsi (Azwar, 2011).

Hasil penelitian ini sejalan dengan teori tersebut, karena ada banyak faktor yang dapat mempengaruhi perilaku seksual remaja, misalnya ingin coba-coba yang tinggi dan kesadaran diri yang kurang maka remaja tersebut juga akan dapat berperilaku seksual berisiko.

Berdasarkan hasil penelitian yang dilakukan oleh desy (2015) dengan judul hubungan pengetahuan dan sikapremaja tentang kesehatan reproduksi dengan perilaku seksual diketahui distribusi perilaku seksual mayoritas pada kategori tidak beresiko yaitu 89 siswa/siswi $(78,1 \%)$ dan minoritas pada kategori perilaku seksual beresiko yaitu 25 siswa/siswi (21,9\%).

Berdasarkan hasil penelitian yang dilakukan oleh peneliti maka dapat disimpulkan bahwa sebagian besar perilaku responden yang baik dikarenakan pemahaman yang baik tentang perilaku seksual pada masa remaja amat merugikan bagi remaja sendiri termasuk keluarganya, sebab pada masa ini remaja mengalami perkembangan yang penting yaitu kognitif, emosi, sosial dan seksual. Kurangnya pemahaman ini akan mengakibatkan berbagai 


\begin{tabular}{c|c|c}
\hline JURNAL PENELITIAN KESMASY & VOL. 1 NO. 2 & $\begin{array}{c}\text { EDITION: NOVEMBER 2018 - } \\
\text { APRIL 2019 }\end{array}$ \\
\hline & http://ejournal.delihusada.ac.id/index.php/JPKSY & \\
\cline { 2 - 3 } RECEIVED: 16 FEBRUARI 2019 & REVISED: 18 MARET 2019 & ACCEPTED: 20 APRIL 2019 \\
\hline
\end{tabular}

dampak yang amat merugikan kelompok remaja dan keluarganya. Pengetahuan remaja tentang kesehatan reproduksi yang baik sangat memengaruhi perilaku remaja untuk hidup sehat, khususnya yang terkait dengan kesehatan reproduksi. Peningkatan angka perilaku seksual remaja disebabkan oleh rendahnya pengetahuan remaja tentang seks dan kesehatan reproduksi dimana pengetahuan merupakan salah satu komponen dalam pembentukan sikap seseorang.

\section{Hubungan Pengetahuan Dengan Perilaku Seks Pranikah}

Dari total 64 responden yang memiliki pengetahuan baik sebanyak 56 responden $(78,0 \%)$. Berperilaku baik 18 responden $(9,8 \%)$ berperilaku buruk. Sedangkan dari 10 responden $(22,0 \%)$ berperilaku baik, 8 bresponden $(9,8 \%)$ berperilaku buruk.

Hasil penelitian ini didapatkan ada hubungan antara pengetahuan dengan perilaku seksual. Hal ini sesuai dengan pendapat Riyanto (2010) Pengetahuan kesehatan reproduksi sangat penting untuk membatasi perilaku seksual yang kian bebas pada usia remaja terlebih pada masa remaja awal. Berdasarkan hasil uji statistik dengan menggunakan uji chi-square. Diperoleh nilai $p$-value $=0,00$ sehingga dapat ditarik kesimpulan $\mathrm{H}_{0}$ ditolak dan $\mathrm{H}_{\mathrm{a}}$ diterima. $\mathrm{Hal}$ ini ada hubungan yang signifikan antara pengetahuan dengan perilaku seksual.

Ada hubungan yang sangat signifikan antara pengetahuan kesehatan reproduksi dengan intensi perilaku seksual bebas. Endarto dan Purnomo (2010) menemukan hasil bahwa ada pengaruh sebesar $7,6 \%$ pengetahuan kesehatan reproduksi terhadap perilaku seksual remaja. Hasil dari penelitian Dewi (2010) menunjukkan bahwa ada hubungan antara tingkat pengetahuan tentang kesehatan reproduksi terhadap perilaku seksual remaja. Tingkat pengetahuan tentang kesehatan reproduksinya baik maka perilaku seksualnya juga baik. Berdasarkan uraian diatas, bahwa ada hubungan antara pengetahuan dengan perilaku seksual pranikah.

Berdasarkan penelitian yang dilakukan oleh Sari (2014) dengan judul hubungan pengetahuan dan sikap dengan perilaku seksual pada anak SMK bahwa Hubungan Pengetahuan dengan perilaku seksual pranikah pada remaja di SMK Patris ada sebanyak 24 $(42,1 \%)$ siswa yang berpengetahuan baik melakukan perilaku seksual pranikah, sedangkan diantara siswa yang berpengetahuan kurang baik, ada 33 (57,9\%) yang melakukan perilaku seksual pranikah. Dari hasil uji statistik diperoleh nilai $p$-value 0.000 maka dapat disimpulkan adanya Hubungan Pengetahuan dengan perilaku seksual pranikah pada remaja di SMK PATRIA. Hasil ini di dukung oleh survei yang dilakukan oleh WHO di beberapa negara yang memperlihatkan, adanya informasi yang baik dan benar, dapat menurunkan permasalahan reproduksi pada remaja. Dengan demikian dapat dikatakan bahwa semakin tinggi tingkat pengetahuan remaja maka akan semakin baik perilakunya, karena pengetahuan atau kognitif merupakan domain yang sangat penting untuk terbentuknya tindakan seseorang (overt behavior). Sebagaimana dikatakan oleh Notoatmojo (2011) bahwa perilaku yang didasari oleh pengetahuan akan lebih langgeng daripada perilaku yang tidak didasari oleh pengetahuan.

Berdasarkan penelitian pawesti (2013) Hasil penelitian diperoleh ada hubungan yang bermakna antara pengetahuan dengan perilaku seks pada siswa di SMA Negeri 1 Godong, nilai $p$-value $0,000(p<0,05)$. artinya semakin tinggi pengetahuan berarti perilaku seks semakin baik atau tidak ada tindakan seks prankah. Secara teori perubahan perilaku atau mengadopsi perilaku baru itu mengikuti tahap-tahap yang meliputi perubahan pengetahuan, perubahan sikap hingga perubahan praktik.

Berdasarkan hasil penelitian hal ini terbukti dari hasil kuesioner yang telah diisi oleh siswa/I didapatkan pengetahuan baik lebih banyakdibandingan pengetahuan yang kurang selain itu juga didapatkan perilaku seksual pranikah yang baik lebih banyak dibandingkan dengan perilaku seksual pranikah .

\section{Hubungan Sikap dengan Perilaku Seksual Pranikah}

Dari total 64 responden yang memiliki pengetahuan baik 56 responden $(78,0 \%)$. Berperilaku baik 18 responden $(9,8 \%)$ berperilaku buruk. Sedangkan dari 10 responden $(22,0 \%)$ berperilaku baik, 8 responden $(9,8 \%)$ berperilaku buruk.

Hasil dari penelitian ini didapatkan ada hubungan antara sikap dengan perilaku seksual pranikah. Hal ini sesuai dengan 


\begin{tabular}{c|c|c}
\hline JURNAL PENELITIAN KESMASY & VOL. 1 NO. 2 & $\begin{array}{c}\text { EDITION: NOVEMBER 2018 - } \\
\text { APRIL 2019 }\end{array}$ \\
\hline & http://ejournal.delihusada.ac.id/index.php/JPKSY & \\
\cline { 2 - 3 } RECEIVED: 16 FEBRUARI 2019 & REVISED: 18 MARET 2019 & ACCEPTED: 20 APRIL 2019 \\
\hline
\end{tabular}

penelitian yang dilakukan sari (2014) Hasil analisis hubungan sikap dengan perilaku seksual pranikah pada remaja di SMK PATRIA menunjukkan bahwa ada sebanyak 43 $(75,4 \%)$ siswa yang mempunyai sikap negatif melakukan perilaku seksual pranikah, sedangkan diantara siswa yang mempunyai sikap positif, ada 14 (24,6\%) yang melakukan perilaku seksual pranikah. Dari hasil uji statistik diperoleh nilai $p$-value 0.000 . Menurut Sarwono (2012), semakin tinggi sikap positif (permisif) terhadap perilaku seksual pada remaja mengakibatkan semakin besar kecenderungan remaja untuk melakukan hubungan fisik yang lebih jauh dengan lawan jenis. Penelitian Dariyo dan Setiawati (dalam Amiruddin, 2011) juga memperoleh hasil bahwa memang terdapat hubungan antara sikap terhadap perilaku seksual dengan intensi untuk melakukan hubungan seksual. Ini berarti semakin positif sikap remaja terhadap perilaku seksual maka semakin besar intensinya untuk melakukan perilaku seksual sedangkan remaja yang memiliki sikap yang negatif terhadap perilaku seksual akan semakin kecil intensinya untuk melakukan perilaku seksual. Berdasarkan penelitian Fitriana (2011) diperoleh ada hubungan yang bermakna antara sikap dengan perilaku seks pada siswa di SMA, nilai $p$-value $0,017<0,05$ ). Digunakan uji Rank Spearman didapatkan nilai $r$ sebesar 0,268 artinya semakin positif sikap berarti semakin baik perilaku seks pranikah. Sikap sebagai bentuk dari perilaku yang masih tertutup sangat erat kaitannya dengan perilaku sendiri. Pengetahuan dan sikap merupakan sama-sama bentuk dari faktor perdisposisi dari perilaku, pengetahuan dan sikap dapat berjalan seiring artinya jika seseorang memiliki pengetahuan yang baik maka akan ada kecenderungan sikap yang positif. Salah satu bentuk stimulus sikap dari luar adalah pengetahuan maka dengan remaja yang mendapat informasi yang benar tentang seksual pranikah maka mereka akan cenderung mempunyai sikap negatif. Seseorang setelah mengetahui stimulus atau objek kesehatan, kemudian mengadakan penilaian atau pendapat terhadap apa yang diketahui, proses selanjutnya diharapkan akan dapat melaksanakan atau mempraktekkan apa yang diketahui atau disikapi sehingga pengetahuan seksual pranikah dapat mempengaruhi sikap individu tersebut terhadap seksual pranikah (Notoatmodjo, 2011).

Kesesuaian hasil penelitian-penelitian ini mengindikasikan bahwa sikap merupakan predisposisi (penentu) yang memunculkan adanya perilaku yang sesuai dengan sikapnya. Sikap tumbuh diawali dari pengetahuan yang dipersepsikan sebagai suatu hal yang baik (positif) maupun tidak baik (negatif), kemudian diinternalisasikan ke dalam dirinya (Dalimunthe, dkk, 2012). Ini juga sesuai dengan teori L. Green yang menyatakan bahwa faktor predisposisi dalam hal ini sikap berhubungan dengan perilaku seseorang.

Berdasarkan hasil penelitian hal ini terbukti dari hasil kuesioner yang telah diisi oleh siswa/I didapatkan sikap negatif lebih banyak dibandingan sikap positif yang selain itu juga didapatkan perialku seksual pranikah yang baik lebih banyak dibandingkan dengan perilaku seksual yang buruk.

Bila dilihat dari jawaban responden atas beberapa pertanyaan yang memberikan respon negatif lebih dari $50 \%$ responden yang menjawab tidak setuju bahwa pendidikan seks dan kesehatan reproduksi perlu diberikan mereka menganggap bahwa itu tidak penting bagi remaja karena membahas perubahanperubahan baik secara fisik maupun anatomi dan sebagian responden menyetujui melakukan hubungan seksual. Penelitian yang dilakukan oleh Soetjiningsih (2011) pada siswa SMA $60 \%$ responden menyatakan bahwa tingkat perilaku seksual yang boleh dilakukan sebelum menikah adalah sampai dengan ciuman bibir sambil berpelukan, dapat dikatakan aktifitas seksual berupa ciuman kini dianggap biasa atau hal yang wajar, sehingga banyak dilakukan oleh remaja.

\section{Kesimpulan}

Berdasarkan pembahasan hasil peneltian yang dilakuakn di SMPN 10 Batam Tahun 2018, dapat disimpulkan bahwa:

1. Mayoritas pengetahuan dengan kategori tinggi yaitu sebanyak 64 responden $(78,0 \%)$ dari 82 responden.

2. Mayoritas sikap dengan kategori negatif yaitu sebanyak 48 responden $(58,5 \%)$ dari 82 responden.

3. Mayoritas perilaku seksual pranikah dengan kategori baik sebanyak 66 responden $(80,5 \%)$ dari 82 responden. 


\begin{tabular}{|c|c|c|}
\hline JURNAL PENELITIAN KESMASY & VOL. 1 NO. 2 & $\begin{array}{c}\text { EDITION: NOVEMBER } 2018- \\
\text { APRIL } 2019\end{array}$ \\
\hline & http://ejournal.delihusada.ac.id/index.php/JPKSY & \\
\hline
\end{tabular}

4. Berdasarkan hasil uji chi-square didaptkan bahwa nilai $p$-value $0,00<0,5$ dapat disimpulkan bahwa ada hubungan yang signifikan antara pengetahuan dengan perilaku seksual pranikah di SMPN 10 Batam Tahun 2018.

5. Berdasarkan hasil uji chi-square didapat bahwa nilai $p$-value 0,01 $<0,5$ dapat disimpulkan bahwa ada hubungan antara sikap dengan perilaku seskual pranikah di SMPN 10 Batam Tahun 2018.

\section{DAFTAR PUSTAKA}

Astuti, (2012). Kesehatan Reproduksi. Yogyakarta : Fitramaya

Azwar, (2011). "Sikap Manusia teori dan pengukurannya". Yogyakarta : Pustaka Pelajar Offset.

BKKBN, (2011). Remaja dan SPN: Seks Pranikah. Diakses: www.bkkbn.go.id pada tanggal 1 Maret 2010.

Damasih. (2011). Kesehatan Reproduksi. Yogyakarta: Fitra Maya.

Depkes R.I 2012. SKRT, diakses pada 13 Maret 2018, http//www.depkes.go.id

Dewi, (2011). Hubungan tingkat pengetahuan dan sikap remaja dengan perilaku tentang seksual pranikah di Semarang.

Dewi, (2012). Hubungan peran orang tua dengan sikap seksual pranikah remaja, Yogyakarta : Stikes Aisyiyah Yogyakarta

Dewi, (2012). Teori dan pengukuran Pengetahuan Sikap dan Perilaku Manusia. Yogyakarta: Muha Medika.

Dheny. (2011). Hubungan tingkat pengetahuan kesehatan reproduksi dengan perilaku seksual remaja pada siswa kelas XI di SMA Batik 1 Surakarta.

Dinas Pendidikan Kota Batam. (2017) Profil Dinas Pendidikan Kota Batam Tahun 2017.

Elcya, (2014) Hubungan Antara Pengetahuan dan Sikap Remaja Dengan Tindakan Seks Pranikah pada Siswa Kelas XI Di SMK Negeri 2 Manado, jurnal kedokteran komunitas dan tropik.

Ganiajri, F., Winarni, S., \& Husodo, B. T. 2012. Perbedaan Pemanfaatan Multimedia flash dan ceramah sebagai media pendidikan kesehatan reproduksi remaja bagi Remaja Awal di SMPN Negeri Turi Kabupaten sleman. Jurnal Kesehatan Masyarakat. Vol. 1, No.2. Semarang : UNDIP

Irianto. (2011). Memahami seksologi : Sinar

Kusmiran. (2011). Kesehatan Reproduksi Remaja dan Wanita. Jakarta: Salemba Medika.

Kustanti. (2013). Kesehatan Reproduksi Remaja dan Wanita. Jakarta: Salemba Medika.

Marmi, (2013). Kesehatan Reproduksi. Yogyakarta: Pustaka Pelajar.

Mubarak dan Chayatin, (2011). Teori dan Aplikasi IImu Kesehatan Masyarakat Pendidikan Kesehatan, Konsep Perilaku dan Perilaku Kesehatan. Jakarta: Salemba Medika.

Nevid, (2011). Perilaku seksual remaja dalam tumbuh kembang remaja dan permasalahannya. Jakarta: Sagung Seto.

Notoatmodjo, (2011). Pengantar Pendidikan Kesehatan dan IImu Perilaku Kesehatan. Yogyakarta: Andi Offset.

Rohan. (2013). Buku Ajar Kesehatan Reproduksi. Yogyakarta: Nuhamedika.

Romauli, Suryati dan Vindari, (2012). Kesehatan Reproduksi Buat Mahasiswa Kebidanan. Yogyakarta: Nuha Medika

Rumengan. (2012). Metodologi Penelitian Kesehatan, Medan: Perdana Mulya Sarana.

Sarwono, (2011). Psikologi Remaja. Jakarta: Raja Grafindo Persada.

Sarwono. (2013). Psikologi Remaja. Jakarta: Raja Grafindo Persada.

SDKI. (2012). Laporan Pendahuluan Masalah Kesehatan Reproduksi Pada Remaja. Jakarta: Pusat Statistik; BKKBN.

Soetjiningsih, (2011). Buku Ajar: Tumbuh Kembang Remaja dan Permasalahannya. Jakarta: Sagung Seto.

Sugiyono. (2011). Metodologi Penelitian Kesehatan. Jogjakarta: Medika Cendikia. 


\begin{tabular}{|c|c|c|}
\hline JURNAL PENELITIAN KESMASY & VOL. 1 NO. 2 & $\begin{array}{c}\text { EDITION: NOVEMBER } 2018- \\
\text { APRIL } 2019\end{array}$ \\
\hline & http://ejournal.delihusada.ac.id/index.php/JPKSY & \\
\hline
\end{tabular}

Suryoputro, (2012). Faktor-faktor yang mempengaruhi seksual remaja di Jawa tengah implikasinya terhadap kebijakn dan layanan kesehatan seksual dan reproduksi.
Wawan, A \& Dewi, M. (2011). Teori dan pengukuran Pengetahuan, Sikap dan Perilaku Manusia. Yogyakarta: Muha Medika.

Yusuf, (2011) Remaja dan Hubungan Seksual Pranikah. http//www.matabumi.com. 